\title{
Labile and Recalcitrant Carbon in Crop Residue and Soil under No-Till Practices in Central Region of Argentina
}

\author{
A. Abril ${ }^{*}$ N. Casado-Murillo, C. Vázquez and P. Olivera
}

Facultad de Ciencias Agropecuarias. Universidad Nacional de Córdoba. Cc 509, 5000, Córdoba, Argentina

\begin{abstract}
We evaluated the effects of the amount and type of C compounds (labile/recalcitrant) of crop residues on the soil organic matter (SOM) components under no-tillage practices in semiarid region of Argentina, with the aim of establishing criteria for sustainable agriculture. Five agricultural situations were evaluated: soybean/wheat rotation (wheat crop and at bare fallow); soybean monoculture; soybean/maize rotation and maize/wheat/potato rotations with biannual ploughing. In each situation crop residues and soil samples were collected. In residue samples, biomass (total and components), organic carbon, insoluble fibers, and soluble C compounds were evaluated. In soil samples total SOM, non-humic substances (NHS), humic substances (HS), humic (HA), and fulvic acids (FA) were analyzed. The total biomass and its components differed among situations and were lower in the situation with plough, while the fiber contents were higher in situations that includes wheat crop. Total SOM, NHS, HA content were higher in the plowed situation $\left(57.20 \mathrm{~g} \mathrm{~kg}^{-1}, 47.30\right.$ $\mathrm{g} \mathrm{kg}^{-1}, 7.80 \mathrm{~g} \mathrm{~kg}^{-1}$ respectively). We concluded that the total SOM quantity in continuous no-tillage is not affected by the different crop rotations and sequences, but the HA quantity (stable SOM) seems to be favored by the high recalcitrant compounds amount of the crop residues (particularly wheat). For these reasons, the following criteria for sustainable agriculture management in semiarid zones can be suggested: a) continuous no-tillage utilization; b) summer crop annual rotations; and c) winter wheat crop instead of bare fallow.
\end{abstract}

Keywords: Fibers, Soluble C compounds, Crop residue biomass, Crop residue components, Humic substances, Soil organic matter.

\section{INTRODUCTION}

The wide diffusion of no-till systems (NT) in some agricultural regions was due to the many advantages in economic, productive and environmental aspects, for example lower fuel consumption, lower soil erosion, higher crop yields, lower $\mathrm{CO}_{2}$ emissions, increases of soil organic matter (SOM), etc. [1-3].

However, many of these beneficial aspects of the NT are still under study because of the high variability of data and the discrepancy in the available information, particularly about the increase of SOM and its consequent implication in $\mathrm{C}$ sequestration $[1,2,4-6]$. Much of the differences between studies have been explained by the many factors affecting the NT, such as weather conditions, management type, previous crops, time since the adoption of NT, etc. [2, 7-10].

Most available information of the NT effect on soil has been obtained in humid and sub-humid regions [10-13]. However, little information from more arid regions with high climate variability, both seasonal and inter-annual is available $[2,14,15]$. Moreover, in most studies of NT effect on SOM, the focus of analysis is made on the relationship between the harvest residue characteristics and the total SOM $[6,13]$. It is well known that each crop produces

*Address correspondence to this author at the Facultad de Ciencias Agropecuarias. Universidad Nacional de Córdoba. Cc 509, 5000, Córdoba, Argentina; Tel/fax: 54351 4334105/03; E-mail: aabril@agro.unc.edu.ar different quantity and quality of residue, however the $\mathrm{C}$ type compounds (labile or recalcitrant) that the residues can turnover to soil depends on the weather conditions that define the decomposition dynamics of the residue chemical components [16]. For these reasons the residue $\mathrm{C}$ compounds can vary substantially from harvest, particularly if the residue remains for years without decomposition (older weathered remaining residue). The remaining residues are especially relevant in long term NT systems, but are rarely considered [1].

It is widely known that SOM is a heterogeneous substance, which includes low molecular weight compounds (non-humic substances) and high molecular weight compounds (humic substances) [17]. The non-humic substances are easily decomposable by microorganisms and they can undergo leaching [18]. Contrarily, the humic substances are highly resistant to biodegradation and strongly associated to soil mineral phase, and they are considered the stable SOM [19].

It has been demonstrated that the proportion of both SOM compounds, non-humic and humic substances, depends on the quantity and $\mathrm{C}$ type of organic residues [20, 21]. Residues with high proportion of labile compounds (soluble C) contribute to non-humic substances content, while residues with high $\mathrm{C}$ recalcitrant content (insoluble fiber) favor the humic substances synthesis [22, 23].

Moreover, humic substances can be separated into fulvic and humic acids on the basis of their solubility. Fulvic acids are soluble in both alkali and acid, and humic acids are solu- 
ble in alkali but precipitate in acid. These fractions differ in molecular size and functional group content, particularly in aromatic group proportion [17]. Accordingly, humic acids are more polymerized and aromatized than fulvic acids, and in consequence, the fulvic/humic acids ratio indicates the SOM maturity degree [24].

The sustainable productivity in agroecosystems focuses on goals to maintain and improve SOM content, particularly stable components (humic substances). However, the mechanisms that are responsible for the humus synthesis are not sufficiently understood. From this point of view, the analysis of the relationship between residue and soil labile/recalcitrant C may contribute to fill this gap [25].

In the central zone of Argentina (semiarid), there is a clear tendency to the advance of agriculture on rangelands. Due to the particular climatic conditions of this zone, farmers apply crop management practices under NT different from that applied in humid zones [2]. Because the rains are concentrated in the summer, the most common cropping systems are: a) summer rainfed crop (with and without crop rotation) with bare fallow during winter, b) summer rainfed crop (with and without crop rotation) with bare fallow or cereal crop during winter, and c) irrigated crop with different annual crop sequences. These variations in the crop management practices strongly affect the relationship between residue and soil compounds. Therefore, detailed analysis is justified to provide a pattern of stable SOM dynamics under NT for the semiarid regions.

In this study we evaluated, realistic conditions from agriculture farms, the effect of the amount and type of $\mathrm{C}$ compounds (labile/recalcitrant) of crop residues on the SOM components under more frequent NT management practices in central region of Argentina, with the aim of establish criteria for sustainable agriculture in semiarid zones.

\section{MATERIALS AND METHODS}

The study was conducted in central semiarid zone of Argentina which is characterized by flat to gently undulating relief. The original vegetation corresponds to marginal Chaco Woodland [26] with predominance of xerophytic species of low size and dense shrub stratum and summer grasses. The climate is template-warm with a precipitation gradient East-West $(850-500 \mathrm{~mm})$. The rainfall is concentrated in summer. Three study sites were selected within the central zone according to the precipitation gradient, which present different histories of crop systems management. Accordingly, we defined 5 situations of analysis (Table 1).

\section{SAMPLING DESIGN}

Sampling design was similar in all situations. In each site, 3 crop residues $\left(0.16 \mathrm{~m}^{2}\right)$ and 3 composite samples $(10$ subsamples) of soil $(0-20 \mathrm{~cm})$ were taken. The samples were collected in the period without crops to avoid the influence of living roots. Thus, the sampling dates were: a) on December in 1-site, immediately after wheat harvest (1SW) and at final of bare fallow period (1SF); b) on August in 2-site, in the middle of the bare fallow period (three months) for two situations (2SF and 2SMF); and c) on July in 3-site, immediately before wheat sowing (3MWP) (Table 1).

\section{LABORATORY ANALYSIS}

Crop residue samples were weighted and fractionated to determine: a) total residue biomass, b) soybean residue biomass, c) wheat residue biomass, d) maize residue biomass, and e) non identifiable residue biomass (NIR), that consist in the older weathered remaining residue. For chemical analysis, crop residue samples were oven-dried at $60^{\circ} \mathrm{C}$ (until constant weight), and milled, to determine: a) organic carbon (ROC) by wet digestion method [27], modified for plant material [28], b) insoluble fibers by enzymatic gravimetric method [29], and c) soluble $\mathrm{C}$ after extraction with water at $80^{\circ} \mathrm{C}[30]$ and wet digestion method.

Soil samples were air-dried for 24 hours and sieved through a $2 \mathrm{~mm}$ mesh. For each soil sample, we measured: a) total SOM (SOMt) content by the wet digestion method of Walkley and Black [27] and b) humic substances content (HS) by alkali extraction $(\mathrm{NaOH})$. In the extract, the humic acids (HA) were precipitate with $\mathrm{H}_{2} \mathrm{SO}_{4}$, and fulvic acids (FA) were calculate by difference between HS and HA [18].

\section{CALCULATIONS AND STATISTICAL ANALYSIS}

The following calculations were made with soil and crop residue data: NHS: non-humic substances (SOMt-HS); HI: humification index (HA/SOMt); PI: polimerization index (HA/FA), [21, 18] and NRC: net recalcitrant C of crop residue (insoluble fibre concentration $\mathrm{x}$ total residues biomass). Differences among situations were analyzed using ANOVA and Tukey test for means comparison $(\mathrm{P} \leq 0.05)$. Pearson correlation analysis was performed to test for linear relationships between soil and residue variables $(\mathrm{P} \leq 0.05)$.

\section{RESULTS}

\section{Crop Residue Characteristics}

Total residue biomass and its components (soybean, maize, wheat and NIR) differed significantly among situations (Table 2). The total residue biomass was lower in 3MWP than other situations. In the situations that present soybean residue (1-site and 2-site), the lowest biomass was detected in 2SMF, while situations with wheat residues (1site) showed the highest values in $1 \mathrm{SW}$. The maize residues biomass was higher in $2 \mathrm{SMF}$ than in 3MWP, while NIR was higher in $1 \mathrm{SF}, 2 \mathrm{SF}$ and $2 \mathrm{SMF}$, which differed from $1 \mathrm{SW}$ and 3MWP.

The insoluble fiber and soluble $\mathrm{C}$ values showed significant differences among situations, while ROC content did not differ (Table 2). Fibers values were highest in 3MWP and in the both 1-site situations (1SF and 1SW), and the lowest values were detected at 2-site (2SF and 2SMF). Accordingly, the net recalcitrant $\mathrm{C}$ values $\left(\mathrm{kg} \mathrm{ha}^{-1}\right)$ were higher in the two situations of 1-site, but $1 \mathrm{SF}$ did not differ of 2SMF (Table 2). The soluble $\mathrm{C}$ compounds were higher in $3 \mathrm{MWP}$ and $1 \mathrm{SW}$ and lower in the two situations of 2-site (Table 2).

\section{Soil C Compounds}

The 3-site showed the highest SOMt, NHS and HA values, while 1-site showed the lowest SOMt and NHS values. The HA content of $1 \mathrm{SW}$ situation was the highest and similar to 3MWP. The situation of 2-site generally 
Table 1. Study Site Characteristics in Agricultural Zone of Central Region of Argentina

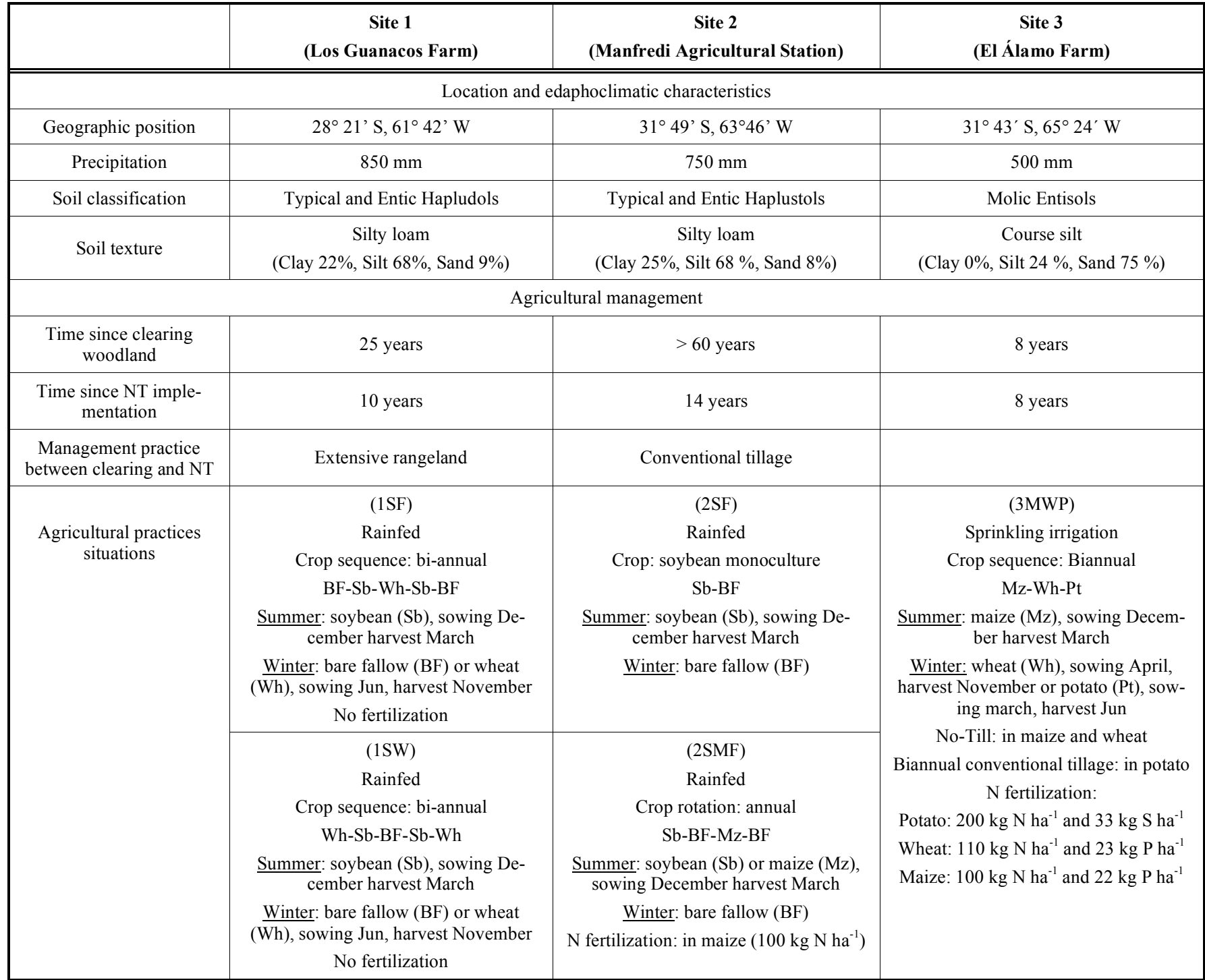

Table 2. Crop Residue Characteristics in the Study Sites. Site Descriptions in Table 1. Letters Indicate Significant Differences Among Crop Situations

\begin{tabular}{|c|c|c|c|c|c|}
\hline & \multicolumn{2}{|c|}{$\begin{array}{c}\text { Site } 1 \\
\text { (Los Guanacos Farm) }\end{array}$} & \multicolumn{2}{|c|}{$\begin{array}{c}\text { Site } 2 \\
\text { (Manfredi Agricultural Station) }\end{array}$} & \multirow{2}{*}{$\begin{array}{c}\text { Site } 3 \\
\text { (El Álamo Farm) } \\
3 \text { MWP } \\
\end{array}$} \\
\hline & $1 \mathrm{SF}$ & $1 \mathrm{SW}$ & $2 \mathrm{SF}$ & 2 SMF & \\
\hline $\begin{array}{l}\text { Total biomass } \\
\qquad\left(\mathrm{kg} \mathrm{ha}^{-1}\right)\end{array}$ & $11476.1 \mathrm{~b}$ & $18235.5 \mathrm{a}$ & $6166.2 \mathrm{bc}$ & $11972.3 \mathrm{~b}$ & $4064.8 \mathrm{c}$ \\
\hline $\begin{array}{l}\text { Soybean residue } \\
\qquad\left(\mathrm{kg} \mathrm{ha}^{-1}\right)\end{array}$ & $5641.8 \mathrm{a}$ & $5632.7 \mathrm{a}$ & $3555.2 \mathrm{~b}$ & $2780.0 \mathrm{~b}$ & $0.0 \mathrm{c}$ \\
\hline $\begin{array}{l}\text { Wheat residue } \\
\qquad\left(\mathrm{kg} \mathrm{ha}^{-1}\right)\end{array}$ & $1469.6 \mathrm{~b}$ & $10167.0 \mathrm{a}$ & $0.0 \mathrm{c}$ & $0.0 \mathrm{c}$ & $0.0 \mathrm{c}$ \\
\hline $\begin{array}{l}\text { Maize residue } \\
\qquad\left(\mathrm{kg} \mathrm{ha}^{-1}\right)\end{array}$ & $0.0 \mathrm{c}$ & $0.0 \mathrm{c}$ & $0.0 \mathrm{c}$ & $5695.8 \mathrm{a}$ & $2770.2 \mathrm{~b}$ \\
\hline $\begin{array}{l}\text { Non identificable } \\
\text { residue (NIR) }\left(\mathrm{kg} \mathrm{ha}^{-1}\right)\end{array}$ & $3611.9 \mathrm{a}$ & $1835.1 \quad b$ & $2610.9 \mathrm{a}$ & 2920.6 a & $303.7 \mathrm{c}$ \\
\hline $\begin{array}{l}\text { Organic carbon } \\
(\mathrm{ROC})\left(\mathrm{g} \mathrm{kg}^{-1}\right)\end{array}$ & $542.51 \mathrm{a}$ & $458.73 \mathrm{a}$ & $519.03 \mathrm{a}$ & $482.10 \mathrm{a}$ & $455.20 \mathrm{a}$ \\
\hline
\end{tabular}




\begin{tabular}{|c|c|c|c|c|c|}
\hline & \multicolumn{2}{|c|}{$\begin{array}{c}\text { Site 1 } \\
\text { (Los Guanacos Farm) }\end{array}$} & \multicolumn{2}{c|}{$\begin{array}{c}\text { Site 2 } \\
\text { (Manfredi Agricultural Station) }\end{array}$} & 2 SMF \\
\cline { 2 - 6 } & $\mathbf{1 ~ S F}$ & $\mathbf{1 ~ S W}$ & $\mathbf{2 ~ S F}$ & $500.7 \mathrm{~b}$ & $\mathbf{3}$ MWP \\
\hline \hline $\begin{array}{c}\text { Insoluble fibres } \\
\left(\mathrm{g} \mathrm{kg}^{-1}\right)\end{array}$ & $840.2 \mathrm{a}$ & $840.9 \mathrm{a}$ & $320.0 \mathrm{~b}$ & $530.9 \mathrm{a}$ \\
\hline $\begin{array}{c}\text { Soluble carbon } \\
\left(\mathrm{g} \mathrm{kg}^{-1}\right)\end{array}$ & $7.57 \mathrm{~b}$ & $8.22 \mathrm{ab}$ & $5.63 \mathrm{c}$ & $9.08 \mathrm{c}$ \\
\hline $\begin{array}{c}\text { Net recalcitrant C } \\
(\mathrm{NRC})\left(\mathrm{kg} \mathrm{ha}^{-1}\right)\end{array}$ & $9.67 \mathrm{ab}$ & $15.53 \mathrm{a}$ & $2.00 \mathrm{c}$ & $5.40 \mathrm{bc}$ & $3.40 \mathrm{bc}$ \\
\hline
\end{tabular}

Table 3. Soil Organic Matter Characteristics in the Study Sites. Site Descriptions in Table 1. Letters Indicate Significant Differences Among Crop Situations

\begin{tabular}{|c|c|c|c|c|c|}
\hline & \multicolumn{2}{|c|}{$\begin{array}{c}\text { Site } 1 \\
\text { (Los Guanacos Farm) }\end{array}$} & \multicolumn{2}{|c|}{$\begin{array}{c}\text { Site 2 } \\
\text { (Manfredi Agricultural Station) }\end{array}$} & \multirow{2}{*}{$\begin{array}{c}\begin{array}{c}\text { Site } 3 \\
\text { (El Álamo Farm) }\end{array} \\
\text { 3 MWP } \\
\end{array}$} \\
\hline & $1 \mathrm{SF}$ & $1 \mathrm{SW}$ & $2 \mathrm{SF}$ & 2 SMF & \\
\hline $\begin{array}{l}\text { Non-humic substances (NHS) } \\
\qquad\left(\mathrm{g} \mathrm{kg}^{-1}\right)\end{array}$ & $26.60 \mathrm{bc}$ & $24.10 \mathrm{c}$ & $29.70 \mathrm{~b}$ & $29.40 \mathrm{~b}$ & $47.30 \mathrm{a}$ \\
\hline $\begin{array}{l}\text { Fulvic acids } \\
\left(\text { FA) }\left(\mathrm{g} \mathrm{kg}^{-1}\right)\right.\end{array}$ & 2.80 & 2.00 & 2.00 & 2.90 & 2.20 \\
\hline $\begin{array}{l}\text { Humic acids } \\
\text { (HA) }\left(\mathrm{g} \mathrm{kg}^{-1}\right)\end{array}$ & $5.10 \mathrm{~b}$ & $8.00 \mathrm{a}$ & $4.80 \mathrm{~b}$ & $5.50 \mathrm{~b}$ & $7.80 \mathrm{a}$ \\
\hline
\end{tabular}

showed intermediate values (Table 3). The HI followed similar pattern that $\mathrm{HA}$ content: $1 \mathrm{SW} \leq 3 \mathrm{MWP}=2 \mathrm{SF} \geq 2 \mathrm{SMF}=$ $1 \mathrm{SF}$, while pattern of PI was: $1 \mathrm{SW} \geq 3 \mathrm{MWP} \geq 2 \mathrm{SF} \geq 2 \mathrm{SMF}$ $=1 \mathrm{SF}$ (Table $\mathbf{3})$.

The following significant correlation were detected between: a) PI with NIR (negative), (Fig. 1a), b) HI with wheat residue biomass and total residues biomass (Fig. 1b), and c) NRC with wheat residue (Fig. 1c).

\section{DISCUSSION}

\section{Total and Component Residue Biomass}

It is well known that the quantity of crop residue on soil surface (including the remaining residue from previous years), is strongly impacted by the tillage system and the crop rotations $[6,31]$. In our study, the total residue biomass in the analyzed different situations clearly responds to both factors (tillage and crop rotations) as well at the time since the new residue deposition [14]. Accordingly, due to the proximity of the wheat harvest, the $1 \mathrm{SW}$ is the situation with the highest amount of residue biomass.

The crop rotation was very important for total residue biomass in $2 \mathrm{SMF}$ (soybean in rotation with maize) related with annual maize input. It is known that the maize harvest leaves high amount of residues [31, 32]. It is important to note that the annual input of maize residue is not a usual farmers' practice in the semiarid region, where summer rotations are biannual or 3-annual [7, 12].

The tillage system affected the total residue biomass (the lowest values) in 3-site due to its the only site that supports a biannual previous potato crop ploughing. Lopez et al. [22] concluded that mouldboard ploughing incorporates over $95 \%$ of the superficial residue. The fact that the $2 \mathrm{SF}$ situation presents biomass values close to 3MWP would indicate that the soybean monoculture (with winter bare fallow) leaves similar low residue as ploughed site. For this reason the soybean monoculture practice would be not recommended as a sustainable system in a semiarid condition [32].

Although the results of total residue biomass are easily explainable from the available information, it is complex to establish the factors that justify the proportions of residues component that were obtained. For example, the high proportion of wheat remaining residue from previous harvest $(13 \%)$ in 1 SF probably responds to the wheat residue chemical composition (high quantity fibers) and the residue deposition date. It is well known that the fiber fraction is de- 

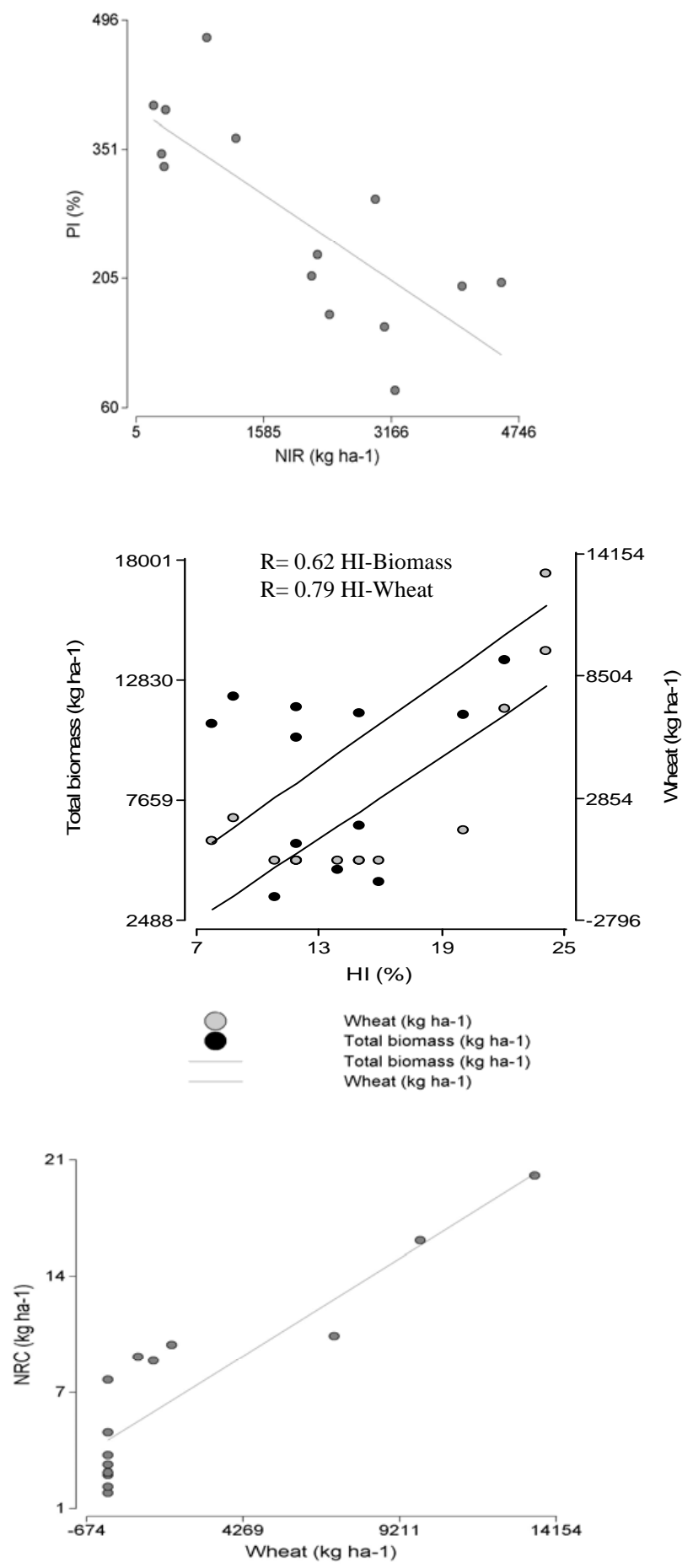

Fig. (1). Significant correlations between crop residue and soil organic matter characteristics.

graded in the second phase of the decomposition process [16], which in this semi-arid region is coincident with the dry winter season [2]. In consequence, the high persistence of one-year-wheat residue would be result of semiarid climatic conditions $[22,33]$. Moreover it is worth to highlight that the crops of 1-site was not $\mathrm{N}$ fertilized. It is widely accepted that $\mathrm{N}$ fertilization favors the microbial activity increasing the residue decomposition rates [33].
Similarly, the high persistence of the soybean residue at six months after harvest in the 1-site-two situations, would respond to the same factors: a) the high residue fiber content (stems), and b) the residue deposition date (beginning of the dry season). In consequence, it is possible to assume that both residue components (wheat and soybean) are degraded mostly during the wet season. This affirmation agrees with Santanatoglia et al., [34] who estimate that the degradation time for $95 \%$ of wheat and soybean residues is similar (approximately 1.5 years).

The differences in maize residue amount between $2 \mathrm{SMF}$ and 3MWP clearly respond to the tillage system. In maize residue under NT, are easily observed the plant recalcitrant components (cobs and stems), which correspond to a previous maize harvest ( 2 year). However, plant recalcitrant components were not observed in 3-site, due to that previous maize residues were incorporated by ploughing. Accordingly, the NIR component in 3-site was the lowest detected.

Few studies mention NIR as a characteristic component of the residue under NT $[1,31,32]$. These authors state that, contrarily to conventional tillage, after many years under NT, old weathered residues (which include a mix of residues from different species and inorganic soil particles) are accumulated. It is noteworthy that the NIR component would be an important and highly mobile nutrient reserve which contributes to the availability of nutrients for future crops [32].

The differences between NIR proportion of both situations of 1 -site $(1 \mathrm{SF}=32 \%$ vs. $1 \mathrm{SW}=10 \%)$ may be due to a winter crop (wheat). The live plant cover provides different soil environmental conditions than bare fallow [2]. It is well known that microorganisms responsible for decomposition of residues are favored by conditions under the live plants: low insolation, low desiccation and scarce temperature variations $[2,12]$. Therefore the NIR degradation could be favored by a winter crop in semiarid regions, with the consequent nutrient release for summer crops [32].

\section{Residue C Recalcitrant Compounds}

The concentrations of recalcitrant compounds found in this work are near between the ranges mentioned by others for the same crops in neighboring agricultural regions. For example, Ernst et al., [16] found $56 \%$ to $62 \%$ range of acid detergent fiber (equivalent to insoluble fiber) $v s$. the $32 \%$ to $84 \%$ range found in this work. The differences may be due to these authors measuring fiber content immediately after harvest, while the most of our situations were evaluated in fallow.

The fact that the recalcitrant compound concentration is very similar in the 1-site-two situations is a very interesting aspect from the agriculture management perspective. Our results indicate that $56 \%$ of wheat residue recently harvested plus $31 \%$ of soybean residue remaining (six month of fallow), is equivalent to $13 \%$ of one-year-wheat residue plus $50 \%$ of soybean (six month of fallow). This comparison indicates that the winter crop favors the continuity in the recalcitrant compound deposition during biannual crop sequence (soybean/fallow/soybean/wheat), although due to the differences in residue biomass, the net fiber is higher after wheat harvest ( $\mathrm{NRC}=10 \%$ vs. 16\%). 
The similar residue fiber concentration found in 2-sitetwo situations (although of 2SMF include both soybean and maize residue and 2SF soybean residue only), agrees with Ernst et al. [16] and Andriulo and Cordone [35], whose found similar fiber content in soybean and maize residue. Therefore, the mentioned higher residue cover in maize rotation reported by several authors may be due to the net fiber amount instead of residue fiber concentration [31, 32]. This state is clear in our NRC results: $2 \mathrm{SF}=2.0 \mathrm{~kg} \mathrm{ha}^{-1}$ vs. $2 \mathrm{SMF}=$ $5.4 \mathrm{~kg} \mathrm{ha}^{-1}$. Moreover, the high recalcitrant compound concentration in $3 \mathrm{MWP}$, results from recently harvested maize residue plus a considerable proportion of lignified stems $(20 \%)$ of a summer weed (Chenopodium sp) (A. Abril personal observation).

The significant correlation between NRC and wheat residue biomass, highlight the important contribution of wheat residue for the soil cover persistence. This result not agrees with the more accepted criteria that the most persistent residue is originated from maize crops [16].

\section{Residue C Labile Compounds}

The variations detected in residue labile compound content are related to dynamic decomposition process. It is widely known that decomposition dynamics include two phases. During the first phase (rapid phase) the decomposition of labile fractions prevails, and in the second phase (slow phase), the decomposition of recalcitrant compounds is the main process $[16,36]$.

Accordingly, the residue labile $\mathrm{C}$ content depends on: a) the fresh residue chemical composition [35], b) the time since residue deposition, and c) the climatic conditions which modified the microbial activity [28, 37-39]. From this point of view, the two situations with higher labile $\mathrm{C}$ content (3MWP and $1 \mathrm{SW}$ ), correspond to recently deposited residues (approximately one month since harvest). Accordingly, the labile compound source is the fresh residue composition. Contrarily, the low labile C contents in 2SF and 2SFW are related with the short winter fallow period ( 3 months). The labile $\mathrm{C}$ compounds in the first phase of decomposition are consumed by microorganisms [16]. The intermediate labile $\mathrm{C}$ values in $1 \mathrm{SF}$ (six months of winter fallow) agree with the second decomposition phase during raining period, which favored the microbial activity (recalcitrant compound degradation and $\mathrm{C}$ labile release) [28].

\section{Relationship Between Residue and Soil Compounds}

Little information is available about the effect of crop residue $\mathrm{C}$ compounds in different cropping and tillage systems of the semiarid region, on SOM compounds. In this work, the significant differences detected in the SOMt content among situations,--may result from the biannual tillage impact instead of the residue chemical characteristics.

The higher SOMt found in 3MWP, where tillage is needed for potato crop, do not agree with the widely accepted concerning that NT have higher SOM content than continuous plowed soils [2,7]. Our results probably arise from the fact that the residues incorporated 1.5 years ago are still in decomposition process, which agree with our results of high NHS content. In this way de Varennes and Torres [15], found that after one year since the residue incorporation, the SOMt increase due the additional $\mathrm{C}$ sources by the ploughing. Bono et al. [2] found that $40 \%$ of the buried residue remains before one year since the ploughing. The discrepancy in the bibliography about differences in SOMt content between conventional tillage and NT [7, 19,6] may be due to that decomposition dynamic generally is not considered.

Also, it is important to mention that 3-site was cleared eight years ago and their original soils have higher SOM content $(5.28 \%)$ [40], than the others sites. In 1-site and 2site conventional tillage agriculture started more than 20 years ago. According to the historic records, the 1-site and 2site soils previous to the NT presented $2 \%$ [41] and $2.6 \%$ of SOMt, respectively [42].

The scarce variation in SOM content in all situations under NT with different rotation systems and crop sequences, agree with Gál et al. [43], who found no differences in total SOM between maize monoculture and maize/soybean rotation after 28 years. Likewise, other authors suggest that residue quantity and rotation system would be not a key factor for $\mathrm{C}$ retention in agriculture soil $[44,45]$. This is in agreement with no significant correlations detected between residue characteristics and total SOM values. Accordingly, absolute amount of $\mathrm{C}$ sequestration under NT in semiarid regions could be associated mainly with climatic conditions [22].

Information about agricultural practice effects on soil $\mathrm{C}$ compounds (humic and non-humic substances) is very scarce, particularly for crops under NT $[11,46]$. The great similarity in HS and FA values detected in all situations suggests that the management practices affects the HA content only, which highlight the importance to use the stable SOM as sustainability indicator $[47,48]$.

It is worth to mention that the most researches on SOM under NT, refer to SOM fractions separate by physical methods (assuming that big size particles correspond to new incorporate SOM) $[49,50]$. However, this physical fragmentation was developed for conventional tillage systems, and in consequence it does not apply for NT system, because residues are not incorporated into soil and this fraction included residues from roots only [19]. For this reason the comparison between information obtained by physical methods and our results would be not adequate and un-realistic.

The fact that the variations in non humic substances did not follow the same pattern that humic substances, would be due to tillage effect. For example, the biannual plowed site (3MWP) presents $82.7 \%$ of NHS vs. $75 \%$ in continuous NT situations, which corroborate the mentioned assumption that SOMt in plowed site includes a great proportion of incorporated residues in decomposition process [15]. Moreover, it is worth to mention that not disturbed soils in 3-site have high content of HA. In un-disturbed soils (Chancaní Reserve), $10.9 \mathrm{mg} \mathrm{kg}^{-1}$ of HA was found (un-published data), accordingly, neighboring 3-site in eight years would have lost approximately $30 \%$ of HA.

The higher HA values and indexes related with humification process (PI and $\mathrm{HI}$ ) in $1 \mathrm{SW}$ may be due to the crop sequence history. The fact that we did not identify remaining wheat residue (corresponding to 2 years ago), indicates the total decomposition of the residue, and in consequence their recalcitrant $\mathrm{C}$ would be incorporated in HA molecules, increasing its concentration $[11,47]$. Our results do not agree 
with Blanco-Canqui and Lal [8], who found that after one year, $33 \%$ of the wheat residue is humified.

The significant correlation detected between $\mathrm{HI}$ and the total and wheat residue biomass agrees with González-Pérez et al., [45], who state that the HA chemical composition is more defined by residue accumulation than by tillage systems and crop sequences. On the other hand, the negative correlation between PI and NIR indicate that the older weathered residues are labile and their contribution to stable SOM is scarce [32]. This agrees with Dieckow et al. [47], who found that under NT the SOM has bigger lability potential.

\section{CONCLUSIONS}

We concluded that: a) the effect of crop residues quantity on the SOM components is very variable and depends mostly on the management practices under NT; b) the biannual frequency tillage strongly affects the total SOM quantity by increasing non-humic substances due to the incorporated residues, therefore, it is recommended more than two years of ploughing frequency to avoid losses of the SOM stable components; and c) the total SOM quantity in continuous NT is not affected by the different crop rotations and sequences, but the HA quantity (stable SOM) seems to be favored by the amount of high recalcitrant compounds of the crop residues (particularly wheat).

Based on our conclusions, the following criteria for sustainable agriculture management in semiarid zones can be suggested: a) continuous NT utilization; b) summer crop annual rotations; and c) winter wheat crop instead of bare fallow.

\section{CONFLICT OF INTEREST}

The authors confirm that this article content has no conflicts of interest.

\section{ACKNOWLEDGEMENT}

Declared none.

\section{REFERENCES}

[1] Oorts K, Merckx R, Gréhan E, et al. Determinants of annual fluxes of $\mathrm{CO}_{2}$ and $\mathrm{N}_{2} \mathrm{O}$ in long-term no-tillage and conventional tillage systems in northern France. Soil Till Res 2007; 95:133-48.

[2] Bono A, Alvarez R, Buschiazzo DE, et al. Tillage effects on soil carbon balance in a semiarid agroecosystem. Soil Sci Soc Am J 2008; 72 (4):1140-9.

[3] Soane BD, Ball BC, Arvidsson J, et al. No-till in northern, western and south-western Europe: A review of problems and opportunities for crop production and the environment. Soil Till Res 2012; 118: 66-87.

[4] Reicosky DC, Archer DW. Moldboard plow tillage depth and short-term carbon dioxide release. Soil Till Res 2007; 94:109-21.

[5] Drewitt G, Wagner RC, Warland J. Isotopic $\mathrm{CO}_{2}$ measurements of soil respiration over conventional and no-till plots in fall and spring. Agr Forest Meteorol 2009; 149: 614-22.

[6] Sombrero A, de Benito A. Carbon accumulation in soil. Ten-years study of conservation tillage and crop rotation in a semi-arid area of Castile-Leon, Spain. Soil Till Res 2010; 107: 64-70.

[7] Alvarez R. A review of nitrogen fertilizer and conservation tillage effects on soil organic carbon storage. Soil Use Manage 2005; 21: 38-52.

[8] Blanco-Canqui H, Lal R. Soil structure and organic carbon relationships following 10 years of wheat straw management in no-till. Soil Till Res 2007; 95: 240-54.
[9] Zanatta JA, Bayer C, Dieckow J, et al. Soil organic carbon accumulation and carbon costs related to tillage, cropping systems and nitrogen fertilization in a subtropical Acrisol. Soil Till Res 2007; 94: 510-19.

[10] Pes LZ, Amado TJ, La Scala N, et al. The primary sources of carbon loss during the crop-establishment period in a subtropical Oxisol under contrasting tillage systems. Soil Till Res 2011; 117: 16371.

[11] Bayer C, Martin-Neto L, Mielniczuk J, et al. Tillage and cropping system effects on soil humic acid characteristics as determined by electron spin resonance and fluorescence spectroscopies. Geoderma 2002; 105: 81-92.

[12] Salado NLR, Sinclair TR. Crop rotations in Argentina: Analysis of water balance and yield using crop models. Agr Syst 2009; 102: 11-6.

[13] Dalal RC, Allen DE, Wang WJ, et al. Organic carbon and total nitrogen stocks in a Vertisol following 40 years of no tillage, crop residue retention and nitrogen fertilisation. Soil Till Res 2011; 112: 133-9.

[14] López-Fando C, Dorado J, Pardo MT. Effects of zone-tillage in rotation with no-tillage on soil properties and crop yields in a semiarid soil from central Spain. Soil Till Res 2007; 95: 266-76.

[15] de Varennes A, Torres MO. Post-fallow tillage and crop effects on soil enzymes and other indicators. Soil Use Manage 2011; 27: 1827.

[16] Ernst O, Bentancur O, Borges R. Decomposition of crop residues under no-till management: wheat, corn, soybeans and wheat after corn or soybeans. Agrociencia (Uruguay) 2002; 6 (1): 20-6.

[17] Prentice AJ, Webb EA. A comparison of extraction techniques on the stable carbon-isotope composition of soil humic substances. Geoderma 2010; 155: 1-9.

[18] Marinari S, Dell' Abate MT, Brunetti G, Dazzi C. Differences of stabilized organic carbon fractions and microbiological activity along Mediterranean Vertisols and Alfisols profiles. Geoderma 2010; 156: 379-88

[19] Pikul JL, Rice J, Chilom G, et al. Organic matter and water stability of field aggregates affected by tillage in South Dakota. Soil Sci Soc Amer J 2009; 73 (1): 197-205.

[20] Almendros G, Zancada MC, Pardo MT. Land use and soil carbon accumulation patterns in South African savanna ecosystems. Biol Fertil Soils 2005; 41: 173-81.

[21] Abril A, Villagra P, Noe L. Spatiotemporal heterogeneity of soil fertility in the Central Monte desert (Argentina). J Arid Environ 2009; 73: 901-6.

[22] Lópes MV, Arrúe JL, Álvaro-Fuentes J, Moret D. Dynamics of surface barley residues during fallow as affected by tillage and decomposition in semiarid Aragon (NE Spain). Eur J Agron 2005; 23: 26-36.

[23] Bahri H, Rasse DP, Dignac MF, et al. Lignin degradation during a laboratory incubation followed by $13 \mathrm{C}$ isotope analysis. Soil Biol Biochem 2008; 40: 1916-22.

[24] Aranda V, Oyonarte C. Characteristics of organic matter in soil surface horizons derived from calcareous and metamorphic rocks and different vegetation types from the Mediterranean highmountains in SE Spain. Eur J Soil Biol 2006; 42: 247-58.

[25] Chabbi A, Rumpel C. Organic matter dynamics in agroecosystems- the knowledge gaps. Eur J Soil Sci 2009; 60: 153-7.

[26] Luti R, Bertrán M, Galera F, et al. In: Vázquez J, Miatello RA, Roque M, (Eds). Geografía Física de la Provincia de Córdoba Buenos Aires: Boldt Press 1979, pp. 297-368.

[27] Nelson DW, Sommers LE. Total carbon, organic carbon, and organic matter. Madison: Methods of Soil Analysis, In: Sparks DL, Pages AL, Helmke PA, et al., Eds. Soil Science Society of America 1996: pp. 961-1010.

[28] Torres PA, Abril AB, Bucher EH. Microbial succession in litter decomposition in the semi-arid Chaco woodland. Soil Biol Biochem 2005; 37: 49-54.

[29] Asp N, Claes G, Johansson G, et al. Rapid enzymatic assay of insoluble and soluble dietary fiber. J Agric Food Chem 1983; 31: 476-82.

[30] Robertson PG, Coleman DC, Bledsoe CS, Sollins P. Standard Soil Methods for Long -Term Ecological Research. New York: Oxford University Press 1999, p. 462.

[31] Abril A, Barttfeld P, Bucher EH. The effect of fire and overgrazing disturbs on soil carbon balance in the Dry Chaco forest. Forest Ecol Manage 2005; 206: 399-405. 
[32] Casado-Murillo N, Abril A. In: Degenovine K, Ed. Crop residue contribution to $\mathrm{N}$ fertilization under long term no-till systems in the central semi-arid region of Argentina. Semi-arid Environments: Agriculture, Water Supply and Vegetation. New York: Nova Science Publishers 2011; pp. 63-82.

[33] Bertol I, Leite D, Zoldan WA. Descomposiçâo do resíduo de milho e variáveis relacionadas. Rev Bras Ci Solo 2004; 28: 369-75.

[34] Santanatoglia OJ, Alvarez R, Barbero N, et al. Decomposition of straw cover and evolution of its nitrogen content in the doubled crop wheat-soybean under direct drilling. Ciencia del Suelo (Argentina) 1994; 12: 63-7.

[35] Andriulo A, Cordone G. In: Panigatti JL, Marelli H, Gil R, (Eds.). Impacto de labranzas y rotaciones sobre la materia orgánica de suelos de la región pampeana húmeda. Siembra Directa, Buenos Aires, Hemisferio Sur 1998; 65-96.

[36] Aita C, Giacomini SJ. Descomposiçâo e liberaçâo çao de nitrogênio de resíduos culturais de plantas de cobertura de solo solteiras e consorciadas. Rev Bras Ci Solo 2003; 27: 601-12.

[37] Paul EA, Clark FE. Soil Microbiology and Biochemistry. San Diego, USA: Academic Press 1996; p. 340.

[38] Noe L, Abril A. Interacción entre calidad de restos vegetales, descomposición y fertilidad del suelo en el desierto del Monte de Argentina. Ecologia Austral 2008; 18: 181-93.

[39] Carranza C, Noe L, Ledesma M, et al. Efecto del tipo de desmonte sobre la descomposición de pastos nativos e introducidos en el Chaco Árido de la Argentina. Revista de Investigaciones Agropecuarias (Argentina). 2012; 38: 97-107.

[40] Noe L, Ascher J, Ceccherini MT, et al. Molecular discrimination of bacteria (organic versus mineral soil layers) of dry woodlands of Argentina. J Arid Environ 2012; 85: 18-26.
[41] Jarsún B, Gorgas J, Bosnero H, et al. Mapa de Suelos Provincia de Córdoba. Buenos Aires Argentina: INTA 1987; p. 82.

[42] Mosconi P, Priano JL, Hein, et al. Mapa de Suelos Provincia de Santa Fe. Buenos Aires, Argentina: INTA 1983; p. 216.

[43] Gál A, Vyn TJ, Michéli E, et al. Soil carbon and nitrogen accumulation with long-term no-till versus moldboard plowing overestimated with tilled-zone sampling depths. Soil Till Res 2007; 96: 4251 .

[44] Roldán AA, Salinas GJR, Alguacil MM, et al. Soil sustainability indicators following conservation tillage practices under subtropical maize and bean crops. Soil Till Res 2007; 93: 273-82.

[45] Soon YK, Arshad MA, Haq A et al. The influence of 12 years of tillage and crop rotation on total and labile organic carbon in a sandy loam soil. Soil Till Res 2007; 95: 38-46.

[46] González-Pérez M, Milori DM, Colnago LA, et al. A laser-induced fluorescence spectroscopic study of organic matter in a Brazilian Oxisol under different tillage systems. Geoderma 2007; 138: 20-4.

[47] Vityakon P. Degradation and restoration of sandy soils under different agricultural land uses in northeast Thailand: a review. Land Degrad Dev 2007; 18: 567-77.

[48] Dieckow J, Bayer C, Concei çâo PC, et al. Land use, tillage, texture and organic matter stock and composition in tropical and subtropical Brazilian soils. Eur J Soil Sci 2009; 60: 240-9.

[49] Cambardella CA, Elliot ET. Particulate soil organic-matter changes across a grassland cultivation sequence. Soil Sci Soc Am J 1992; 56: 777-83.

[50] Alvarez R, Alvarez C. Soil organic matter pools and their associations with carbon mineralization kinetics. Soil Sci Soc Am J 2000; 64: 184-189.

Received: August 11, $2012 \quad$ Revised: November 25, 2012 Accepted: December 03, 2012

(C) Abril et al.; Licensee Bentham Open.

This is an open access article licensed under the terms of the Creative Commons Attribution Non-Commercial License (http:/creativecommons.org/licenses/by-nc/3.0/) which permits unrestricted, non-commercial use, distribution and reproduction in any medium, provided the work is properly cited. 